\title{
Taking issue with how the Work-integrated Learning discourse ascribes a dualistic meaning to graduate employability
}

\author{
Ville Björck ${ }^{1}$ (D)
}

Accepted: 26 October 2020 / Published online: 5 January 2021

(c) The Author(s) 2020

\begin{abstract}
Work-integrated Learning (WIL) is renowned for providing a bridge between 'theory' and 'practice' that fosters 'employable graduates'. This study critically argues that the WIL discourse continues to ascribe a dualistic meaning to graduate employability that primarily contributes to creating the so-called theory-practice gap for students. As an argument towards such a conclusion, a genealogical discourse analysis of how the graduate employability idea operates in 87 present and past official documents concerning the Cooperative Education (Co-op) WIL model is used. Two accounts of graduate employability, the antagonistic practice acclaiming account and the harmonious theory and practice account, recur in both the present and past documents. Both accounts contribute to creating the gap, while the latter also contributes to bridging it. The non-dualistic account, which involves knowing that the key to becoming employable is understanding how both research-based and informal theory shape daily occupational work, could be a useful alternative to these accounts. This is because it could encourage students to see how theory is a form of knowledge manifested in, rather than disconnected from, this work. However, the usual WIL design, whereby universities and workplaces outside universities are respectively institutionalised as the places where 'theory' and 'practice' is learnt, is not so much instrumental in spreading this non-dualistic account, but rather implies to students that 'theory' is absent from daily work until they apply it. Thus, I discuss how establishing physical and/or virtual countersites to the usual WIL design could potentially spread this account to students.
\end{abstract}

Keywords Dualistic vs. non-dualistic · Graduate employability · Theory-practice gap · Work-integrated Learning · Cooperative Education · Genealogy

Ville Björck

ville.bjorck@hv.se

1 Department of Health Sciences, University West, Trollhättan, Sweden 


\section{Introduction}

To foster 'employable graduates', higher education must become more 'practice-based'. This statement sums up a key message of a policy agenda that has been urging higher education institutions (HEIs) worldwide to prepare students for the job market since approximately the mid1990s, namely the employability agenda (Letts 2019). A related aspect of this agenda is that since the mid-1990s, employers and governments have pushed people worldwide to adhere to a neoliberal interpretation of employability (Letts 2019). While the global spread of this interpretation in the 1990s makes it easy to think that the employability idea itself emerged in the late twentieth century, it had already been used as a policy concept in the early twentieth century (Gazier 1998). The neoliberal interpretation claims that contemporary working life is constantly changing and cannot guarantee secure employment, and emphasises that people themselves must deal with this uncertainty by becoming and staying employable. Here, employable means being able to constantly adapt to changes in working life (Garsten and Jacobsson 2004).

Research has problematised that this interpretation stems from a neoliberal governmentality that is widely established in contemporary society (see e.g. Lakes 2011 ). Governmentality is a Foucauldian concept referring to that different modes of governing the conduct of people have been used throughout history (Foucault 1991). In modern times, everyday institutional practices, and the mentalities they spread are especially used to shape the collective and individual conduct of people (Foucault 1991). A neoliberal governmentality (mode of governing) spreads the mentality that each person is largely responsible for their own success or failure in life (Lakes 2011), and, as such, the neoliberal interpretation of employability has been criticised for largely placing the onus on becoming and staying employable on the individual (see e.g Fejes 2010, who problematises this interpretation ).

Furthermore, research has criticised the employability agenda for pressuring HEIs into educating students in the skills that employers demand (Suleman 2018). In this study, I consider this criticism and the criticism of the neoliberal interpretation of the employability idea while exploring a generally ignored research topic, that is, what happens when this idea under the label of graduate employability enters the discourse that is used to discuss different standard models of the form of higher education called Work-integrated Learning (WIL). I label this the WIL discourse, and these various models make use of a standard setup of placement WIL (Jackson 2017). Placement WIL is a popular WIL design (Zegwaard and Rowe 2019) whose standard setup in many degree programmes involves splitting students' education into on-campus training and placement-based training off-campus. I refer to this setup as the usual WIL design, and there is also non-placement WIL, whereby students engage in so-called real-world-like activities on campus to acquire both technical and soft skills (Jackson 2017).

The research topic looks at how the WIL discourse continues to ascribe a dualistic meaning to graduate employability because it remains founded on a theory-practice terminology that uses a dualistic order of discourse ${ }^{1}$ to speak about graduate employability (Björck and Johansson 2019). This means a terminology in which conceptual pairings such as theory-practice, academia-real world, and study-work are used as opposite terms to define graduate employability. I will argue that when said dualistic meaning is spread to students it contributes primarily to the creation, as well as to the bridging of the gap between the stated forms of training that WIL seeks to bridge,

\footnotetext{
1 Here, the concept of order of discourse refers, in a Foucault-inspired manner, to an order for how language is organised and used (Foucault 1971).
} 
the so-called theory-practice gap. In other words, the argument put forward is that this meaning's primary contribution is to create this gap for students, not that the gap exists solely because the WIL discourse continues to spread the meaning in question. In the stated terminology, theory and practice respectively mean the abstract researchbased knowledge in the form of principles and explanatory models, etc. that is taught on campus, alongside the concrete activities carried out at work placements (Björck and Johansson 2019). When I use single quotations marks around theory and practice, I am using these concepts in the same manner as this terminology.

Furthermore, in my previous studies (Björck and Johansson 2019; Björck 2020) and in other studies that also problematise the polarising WIL discourse, the focus has been on ideas that reveal their dualistic nature because their labels include the kind of conceptual pairings stated above (see e.g. Orr 2002 who problematised the notion that there is an 'academia' and a 'real world'). This study adds to contemporary research by problematising an idea whose label does not include such a conceptual pairing and that, in a WIL context, is not known to be ascribed a dualistic meaning that arguably contributes primarily to creating the so-called theory-practice gap, i.e. graduate employability. The purpose is to problematise this dualistic meaning and discuss how a non-dualistic account of graduate employability could be spread to and, in a decisive way, avoid creating this gap for students.

A genealogical discourse analysis of how this idea operates in 87 present and past official documents promoting the Cooperative Education (Co-op) standard WIL model that emerged at the University of Cincinnati in 1906 is used to problematise the said dualistic meaning (Sovilla and Varty 2011). More specifically, 83 of them are paper- or web-based documents, with content produced by the University of Cincinnati, USA, the University of Waterloo, Canada, and University West, Sweden, and distributed between 1928 and 2019 to promote the Co-op model to their prospective and existing Co-op students. Some of these documents are also directed at employers with the intention of maintaining and acquiring new workplaces where prospective or enrolled Co-op students from these HEIs could complete their work placements. The remaining four documents are from 1914, ca. 1930, 1944, and ca. 1960. They also promote Co-op but are either (a) not university-based or (b) documents whose content was originally not produced by HEIs with the intention of promoting Co-op to their prospective and enrolled Co-op students. As the graduate employability idea has been traced back more than 100 years, the documents distributed between 2000 and 2019 were treated as present-day documents.

Furthermore, since 1906, Co-op is typically organised in such a way that students alternate between periods of on-campus training and periods of paid work placement outside the HEIs. Co-op emerged during the second industrial revolution, an event generally dated at between 1870 and 1914. Primarily in Britain, Germany and the US but also elsewhere, this industrial revolution expanded and changed the manufacturing industry to the extent that an increased demand for people with an engineering education oriented towards this industry was created (Sovilla and Varty 2011). In the early twentieth century, US engineering education had generally moved to HEIs (Jolly 2009), and the worldwide norm at the time was that HEIs only offered students a training in 'theory'.

However, a few voices argued that engineering students also needed a 'practice' to be prepared for the changes that had taken place in the manufacturing industry. In connection with these voices, Co-op emerged at the University of Cincinnati's engineering college, an emergence that many 'academicians' opposed because they wanted higher education to be kept separate from working life (Sovilla and Varty 2011). 
Furthermore, there is currently a global trend among HEIs to apply the usual WIL design in their attempts to foster employable graduates (Zegwaard and Rowe 2019). Here, employable graduates mean in general graduates who are ready for the daily practices of a profession and for working life in general (Lau, Baranovich and Leong 2018). There are also other features of the usual WIL design that are important to note. While all different models of this design offer on-campus training and placements at workplaces outside HEIs, they also often differ in certain respects, for instance regarding (a) the number and length of the placements they offer students and (b) whether they offer paid or unpaid placements. Furthermore, while on-campus and work placement-based training are, respectively, in a key way, intended to teach students 'theory' about and the 'practice' of a profession, this does not mean that students only study 'theory' on campus and only carry out 'practice' (concrete work) at placements. However, the WIL discourse implies this, not only by labelling the former way of training 'theory-based' training and the latter 'practice-based' training but also by labelling gaps between these forms of training, theory-practice gaps.

In this study, gaps between the said forms of training are not seen as gaps between abstract theories about how a profession should be practised and a purely concrete professional practice. Rather, they are seen as gaps between the theories and the approaches for applying these theories that students are taught on campus and the theories and the ways of applying them that are tacitly or explicitly used at the students' workplaces.

Furthermore, as long as they are not too extensive, this study does not see gaps between students' on-campus and work placement-based training as a problem, nor does it advocate for a perfect match between what students are taught on campus and at placements (see e.g. Allan and Evens 2019, who criticised the established research focus that such gaps should be bridged). Rather, what I see as problematic for WIL is the reproduction of the very notion that these gaps are theory-practice gaps per se. This is because the said notion provides scope for the dualistic thinking that gaps occur because these forms of training respectively deal with two very different forms of knowledge that often do not combine well. This way of thinking contributes to disconnecting on-campus and work placementbased training for students because it arguably encourages them to question the use of trying to integrate what they have been taught on campus and at work placements.

There are two more bases I need to explain before outlining the previous research section. One is why this study can draw conclusions about how the WIL discourse in general ascribes a dualistic meaning to graduate employability when the empirical material examined concerns the Co-op WIL model. The basis behind this is that there are accounts of the dualistic meaning ascribed to graduate employability that are not specific for statements about Co-op but are general for the WIL discourse. The empirical material includes such types of accounts, and how they were identified is explained in the theorisation and analytical approach section.

The second basis in need of clarification is that this study recognises that there have been changes over time to both how Co-op is applied and to the context in which Co-op is applied, for instance in terms of changed working conditions. However, the present study does not focus on this. Rather, it problematises two interconnected conditions. One is that, since Co-op emerged, the most common format of WIL has in many cases been to split students' education into campus- and work placement-based components with a key intention of this being their training in 'theory' and 'practice', respectively. The other condition is that this split has over time institutionalised a WIL discourse founded on a terminology in which WIL-related notions, such as graduate employability, are ascribed a dualistic meaning. 


\section{Previous research}

Research has emphasised that the employability idea emerged as a policy concept in early twentieth century debates on unemployment (see e.g. Gazier 1998). The current, common neoliberal interpretation of employability was first introduced by corporations in the 1980s and, thereafter, adopted by the policy discourse of governments and the European Union (EU). This interpretation represents a shift from earlier ways of speaking about people as employed or unemployed to speaking about them as employable or unemployable (Garsten and Jacobsson 2004). Research has criticised that a key aspect of this shift is that both the responsibility for being employed and the blame for being unemployed is shifted towards the individual (see e.g. Lakes 2011).

Another notable aspect about the employability idea is that it was in the past, and still is, irrespective of context, often used in a vague way (Gazier 1998; Sin and Neave 2016). Take the WIL context, where this idea is currently often labelled graduate employability, as an example. Here, an employable graduate is currently often used as a tacit term for a work-ready graduate (Lau, Baranovich and Leong 2018), i.e. a graduate that is ready for the ways of working that are established in a profession and in working life in general. I call this the traditional work readiness interpretation of graduate employability because this interpretation is not specific to contemporary society. An example of this is that a key idea behind Co-op's emergence was that Co-op would foster engineers who were ready for the manufacturing industry (Sovilla and Vardy 2011). The said interpretation has also received much criticism in research. Trede and McEwen (2015) emphasised that graduate employability is not only about being ready for but also about being able to question and change established ways of working. Clarke (2018) argued that there is a need to transcend the perspective that HEIs must foster graduates who in the eyes of employers are workready. HEIs are currently also accused by employers and governments for failing to foster such graduates because their education is not connected sufficiently enough to working life (Tomlinson 2017), and the usual WIL design is earmarked as a way for HEIs to foster work-ready graduates (Jackson and Collings 2018; Crisp, Higgs and Letts 2019).

In conclusion to this section on previous research, I want to point out that while there is a current trend in research to speak of employability as something the individual students must acquire for themselves, contemporary research also tends to emphasise that fostering employable (work-ready) graduates should be the joint responsibility of students, HEIs and employers (Crisp, Higgs and Letts 2019).

\section{The empirical material and how a key genealogical principle was used to select it}

The 87 documents I examined were all selected because they promote Co-op by ascribing a dualistic meaning to graduate employability. This meaning was not only promoted in these 87 documents, but also promoted in all documents that I came across when gathering my empirical material. This is not strange because, as stated, the terminology used to discuss the Co-op and other standard WIL models use conceptual pairings such as theory-practice, academia-real world and study-work as opposite terms to explain how such models foster graduate employability. In this study, I was inspired by Foucault's approach to genealogical discourse analysis, a key principle of which is to trace a figure (e.g. an idea) from the present back in time by examining one or more 
types of present and past documents in which this figure is represented (Foucault 1984; Dahlstedt and Fejes 2017). Based on this principle, I traced the graduate employability idea from the present back to the early discourse on Co-op by selecting 87 documents from different dates in the period in which Co-op has existed. Of these documents, 83 have a content originally produced by the University of Cincinnati, USA, the University of Waterloo, Canada, and University West, Sweden, with the primary intention of promoting Co-op to their prospective and existing Co-op students.

Documents from these HEIs were selected because they have a history of using Co-op, and together they have used Co-op since its emergence. More specifically, the three HEIs were first to introduce Co-op in the country where they are located, and respectively the University of Cincinnati, the University of Waterloo and University West began to use Co-op in 1906, in 1957 and in 1989. Assisted by archivists at these HEIs, I found around 200 documents dating back to 1928. Many of them include multiple pages whereas others are shorter in the form of a paper-based information sheet or a text from the website of one of the three HEIs stated above. Moreover, some documents only discuss Co-op, whereas others also discuss other topics such as specific degree programmes.

After reading them carefully, I concluded that they are very similar in terms of how they promote Co-op by ascribing a dualistic meaning to graduate employability. Against this background, I selected 83 such documents using the following selection criteria. I chose documents that were used at different dates between 1928 and 2019, so that together they would provide both explicit and implicit examples of how this meaning is ascribed to graduate employability and used to promote Co-op.

The other four documents selected were published in 1914, ca. 1930, 1944, and ca. 1960. The first document is a transcript of Herman Schneider's 1914 hearing about Cooperative and Vocational Education before the US House of Representatives' Committee on Education, which I obtained from a research contact. Schneider was the dean of the College of Engineering at the University of Cincinnati (UC) who promoted Co-op before its emergence there. The document dated around 1930 is a newspaper article about Co-op at UC, entitled A university based on a new idea. This newspaper article is written by a former journalist named Myron M. Stearns. The document from 1944 is a UC pamphlet entitled Is Higher Education obsolete? This pamphlet comprises six articles initially published in different US newspapers. The document published ca. 1960 is entitled Excerpts from Writings and Speeches about Cooperative Education and is a collection of past quotations about Co-op, several of them voiced by Schneider between ca. 1900 and 1935.

The last three documents were found with the assistance of archivists at UC, and all four stated documents were not only selected because they promote Co-op by ascribing a dualistic meaning to graduate employability. The transcript of Schneider's hearing and the document including excerpts from writings and speeches about Co-op were also selected because they allowed me to trace this meaning further back in time than was possible with the 83 documents described above. Furthermore, the four documents were selected because they provide past examples of the fact that the dualistic meaning ascribed to graduate employability is not only used by HEIs, but is also promoted more broadly in society. 


\section{Theorisation and analytical approach}

In this study, I was not only inspired by a Foucauldian approach to genealogical discourse analysis but also by a Foucauldian interpretation of discourse and power. One of the two working definitions of discourse applied sets out that a discourse is a group of statements that has a main topic, but which also discusses other related topics (Foucault 1972). Present and past statements regarding Co-op were seen to belong to the WIL discourse, a discourse founded on the theory-practice terminology that is mainly used to discuss the Co-op and other standard WIL models, but also to discuss higher education and working life in general. There are also two ways in which these present and past statements follow this terminology's dualistic order of discourse in ascribing meaning to graduate employability. One is antagonistic, using conceptual pairings such as theory-practice, academia-real world, and study-work as terms for rival and/or incompatible opposites, and the other is harmonious, using such pairings to describe opposites that fit well together (see Webb 2013, who emphasised that people generally tend to use these antagonistic or harmonious ways of speaking when treating two concepts as opposite terms). In the 'Results' section, I seek to demonstrate that an antagonistic account of the dualistic meaning ascribed to graduate employability merely contributes to creating the so-called theory-practice gap for students, whereas a harmonious account of this meaning contributes to both creating and bridging that gap.

The second working definition of discourse applied is that a group of statements forming a discourse shape and are also rooted in and (re)produced by our institutions and their practices (Foucault 1990). Thus, I saw the Co-op and other standard WIL models as institutional arrangements that embody and reproduce the messages of the theory-practice terminology and its key ideas. For instance, through the decisive embodiment of the idea that you study an abstract knowledge called 'theory' on campus and carry out concrete work called 'practice' on work placements, these models imply to students that what is taught on campus and during placements are very different things.

Furthermore, inspired by Foucault (1990), I saw and examined power as a productive force that in various shapes, for instance in the form of an assumption, operates through and underlies how we (people) speak about a topic.

This section will now describe how I conducted the genealogical discourse analysis with the intention of problematising how the WIL discourse continues to ascribe a dualistic meaning to graduate employability (see Foucault 1984, who argued that the aim of a genealogical discourse analysis is to problematise how a figure, such as an idea, is discussed at present). As such a discourse analysis starts with the present, I began by examining the contemporary documents on Co-op and applying in this examination a few interrelated analytical processes.

First, I read through the documents several times and took notes of (a) how they used concepts such as theory and practice, academia and real world, and study and work as opposite terms to describe how Co-op creates employable graduates and (b) what these descriptions mean by employable graduates. Based on these notes, I looked through the documents to discern accounts (descriptions) of how graduate employability is created that were not only common there, but that also reflected how WIL in general and not just Co-op is emphasised as a way of fostering graduate employability in contemporary research. I did this to identify accounts that are typical of the general WIL discourse and not specific for statements about Co-op. Two such accounts emerged. By looking into the characteristics of graduate employability in these accounts, I determined that one took on an antagonistic 
approach and the other, a harmonious one. I also explored how and why the antagonistic account could be said to merely contribute to creating the so-called theory-practice gap for students, and how and why the harmonious account could be seen to both contributing to the creation and bridging of this gap.

Furthermore, according to the Foucauldian view that power is a productive force that underlies discourse, I investigated whether and, if so in what ways, there are productive forces, such as assumptions, that underlie these accounts. It was also in connection with the analytical processes previously mentioned that I selected several quotations that belong to the antagonistic and the harmonious accounts.

My next step was to examine the past documents. Since a key focus of genealogical discourse analysis is the comparison of past and present interpretations of a current idea such as graduate employability (Dahlstedt and Fejes 2017), the analysis of these documents focused on two things: to examine whether the antagonistic and harmonious accounts discerned in the present documents also mirrored the accounts of the dualistic interpretation of graduate employability common in the past documents and, if so, whether these accounts have the same characteristics in the present and past documents. It was determined that these accounts mirrored the accounts of this interpretation common in the past documents and that they had the same characteristics in the present and the past documents. Based on this, I selected several past quotations that illustrate these characteristics, and the following results section outlines present and past quotations belonging to the antagonistic and the harmonious accounts.

\section{Results}

In the documents I studied, both accounts generally adopt a work readiness interpretation of graduate employability. This interpretation defines an employable graduate as a graduate who is ready for daily professional work, which here means the daily expert work of an occupation that an individual must train for to be ready for such work. The 'Results' section outlines quotations of these accounts that adopt such an interpretation. Thus, in this section, the term employable graduate is used according to the above stated meaning and graduate employability has the meaning of readiness for daily professional work. Such quotations are outlined because they are common in empirical material and because, in the discussion, I intend to problematise how the said work readiness interpretation is linked to the dualistic meaning that the WIL discourse ascribes to graduate employability. The two accounts of graduate employability are presented separately and are respectively called the antagonistic practice acclaiming account and the harmonious theory and practice account. I start by outlining contemporary quotations to illustrate that current key characteristics of these accounts can be traced back in time and have, over the years, reproduced the dualistic meaning ascribed to graduate employability.

\section{The antagonistic practice acclaiming account}

The key characteristic of this account is that it praises so-called practical or work experience for fostering employable graduates, often by implying rather than stating this explicitly. A quotation that belongs to this account is the following student statement that was available on University West's website in September 2019: 
It was the Co-op that was the decisive factor when I had to choose what to study. I felt that it was great to have the opportunity to get out and work a little. There are also lots of employers who are looking for newly qualified engineers with work experience, and, in this regard, the Co-op is really good (https://www.hv.se/utbildning/ intervjuer/grundniva/maskiningenjor).

By positioning work experience as something that employers seek, this quotation implies rather than explicitly states that this 'experience' fosters employable graduates. Underlying the said account is the assumption that 'practical experience' and craftsmanship, rather than formal schooling and knowledge in 'theory', makes students ready for professional work. This assumption is antagonistic because it represents a devaluation of formal schooling and 'theory', and, in connection with the said assumption, craftsmanship means the 'expertise' that you can only learn from practising an occupation and that professional work is founded upon. The assumption stated above can also be expressed in other words, namely that an employable graduate is a graduate who has the 'practical experience' and thereby the craftsmanship to be ready for professional work.

In the documents studied, instances of the practice acclaiming account seldom voice this assumption explicitly, but instead allude to it, masking the account's antagonistic nature. Some instances do allude to this assumption more clearly, however. For instance, a 2014 University West brochure called CO-OP contains a student quotation emphasising that it is the work periods rather than 'theory' which ensure that 'I learn how you work as an engineer' (p. 7). This quotation alludes to the 'saying' that you do not learn a profession by attending classes and reading books but through work experience, a saying which is also implied in a 2006 University of Cincinnati document where a student states: 'my co-op will provide me with work experience that no classroom or textbook can match' (Celebrating 100 years of Co-op: Growth, Experience and Connections, p. 15). The stated saying reflects a scepticism of formal schooling that can be traced back in time and forms a key foundation for the assumption that it is 'practice' which prepares you for professional work. This scepticism is clarified in connection with a quotation from a 1990s University West document called COOP - The education that will earn you more than just money:

Nothing impresses an employer more than a student who isn't always stuck in the classroom (COOP - The education that will earn you more than just money, p. 2).

This quotation tacitly alludes to the scepticism that formal schooling is too focused on abstract 'theories' to be of 'real' use in 'practice', and thereby unable to foster employable graduates, a scepticism often implied by the examined documents. This scepticism is spread through the antagonistic assumption underlying the practice acclaiming account and by spreading this assumption, albeit often tacitly, this account simultaneously implies that you study a form of knowledge called 'theory' on campus that is of no 'real' use in 'practice'. By implying this, the said account gives students the message that they study a form of knowledge that is not useful in 'practice'. This message arguably contributes to creating the so-called theory-practice gap because it discourages students from trying to connect what they are taught on campus with what they are taught at placements.

Furthermore, many instances of the practice acclaiming account that refer subtly to this account's underlying assumption also contain equally subtle references to the said scepticism of formal schooling. For instance, in a 1977 University of Waterloo Undergraduate Admissions Handbook used ahead of the 1978 spring semester, it is emphasised that Co-op ensures that 'you can learn theory and train for a career at the same time' (p. 5). This subtly suggests that preparation for a career is gained from 'practice' and not from 
reading 'theory', a suggestion which implies that it is 'practice' which makes you ready for professional work, and which subtly reminds students of the scepticism that 'theory' is too abstract to prepare you for such work. This scepticism and the assumption underlying the practice acclaiming account are now further discussed in connection with a quotation that belongs to this account and that appears in Myron M. Stearns' newspaper article about Co-op at the University of Cincinnati (UC) that is dated around 1930 and called A university based on a new idea. The quotation appears in connection with two statements, one of which accuses higher education of being too 'theoretical', and the other discusses the 1906 emergence of Co-op and the idea behind locating parts of students' engineering education in industry:

There (industry author's comment) was the real college that could teach life-in the steel mills, in the machine shops, in the drafting rooms of production plants, in the myriad business offices of industry ( Stearns ca. 1930, p. 82).

By being voiced in connection with the said scepticism, and by implying that industry is the 'real' place for learning industrial work, this quotation alludes to the antagonistic assumption underlying the practice acclaiming account. This assumption forms an asymmetrical ranking order that devalues formal 'schooling' and 'theory' for being unable to foster employable graduates, and praises 'practical experience' for doing so. Such praise is also apparent in the transcript of Herman Schneider's 1914 hearing about Cooperative and Vocational Education before the US House of Representatives' Committee on Education where it is emphasised that work experience ensures that you 'can go right out into a job' after graduation (p. 15).

Furthermore, the practice acclaiming account and the assumption underlying it are not specific to Co-op, but key elements of today's general WIL discourse. Contemporary WIL research praises 'practical experience' for its role in fostering employable graduates (see e.g. Boud 2012; Jackson and Collings 2018) and the assumption that this 'experience', rather than formal schooling and 'theory', fosters such graduates is also emphasised in research (see e.g. Raelin 2016, who argued that work-based and not classroom learning is the ideal preparation for management work). Scepticism of formal schooling is also not just a thing of the past. It is still present among employers, for instance (Masschelein and Simons 2013; Letts 2019). However, although still being established today, this does not mean that the said account, assumption and scepticism are currently unchallenged. The following account of graduate employability is an example of this.

\section{The harmonious theory and practice account}

The key characteristic of this account is that it praises how the mix of training both in 'theory' and in 'practice' fosters employable graduates, often by implying, rather than stating this explicitly. The following text supports this account and was available on the University of Cincinnati's website in November 2018:

Through an on-going alternation of semesters of classroom study and disciplinerelated, paid work semesters, co-op provides students a bridge to integrate theory and practice. The well-structured nature of the program enables students to develop competencies that are deemed important by faculty in the disciplines and by professional practitioners... and program graduates have many advantages when seeking career employment. (https://ceas.uc.edu/future_students/Coop/profe ssional_practicefacultystaffforengineering.html). 
Here, it is implied that students combining on-campus training with work placements gain a bridge between 'theory' and 'practice' that fosters employable graduates. Underlying the theory and practice account are the two assumptions that the basis for professional work is that you know (a) both 'theory' and 'practice' and (b) how to integrate (unite) them. In connection with these assumptions, an employable graduate can be described as a graduate who knows 'theory' and 'practice' and can integrate them. The said assumptions are harmonious because they rate knowledge in 'theory' and 'practice' as being equally vital foundations for professional work. They differ from the antagonistic assumption underlying the practice acclaiming account that positions knowledge in 'practice' as the only foundation for this work.

The theory and practice account and the two assumptions underlying it are not specific to Co-op, but are key elements of today's general WIL discourse. A clear indication of this is that the usual WIL design is emphasised in research as fostering employable graduates by offering students a mix of, and a bridge to integrate, 'theory' and 'practice' (Jackson 2017). The two assumptions underlying this account are seldom voiced explicitly, but instead alluded to in the documents studied. A student quotation in a 2005 University of Waterloo Admissions Brochure for degree programmes in Accounting and Financial Management exemplifies an instance of said account, alluding to the assumption that graduates are only employable if they can integrate 'theory' and 'practice'. The quotation emphasises that employers want graduates who can 'apply what they know in real situations' (p. 1), a quotation alluding to the idea that employers do not want a graduate who is merely well-educated in 'theory', but one who can integrate 'theory' and 'practice'. A student quotation from a 1990s University West document illustrates how an instance of the theory and practice account alludes to the other assumption underlying this account:

I am in a better position than those students who did not opt for the COOP format when it comes to competing for jobs in the labour market. It is important to possess both theoretical and practical ability (Cooperative Education - Putting higher education to work, p. 2).

Here, the assumption that you must know both 'theory' and 'practice' to become an employable graduate is implied by the statement that you are less attractive in the labour market if you do not 'possess both theoretical and practical ability'. Furthermore, because the theory and practice account, albeit often implicitly, spreads the assumption that being able to integrate 'theory' and 'practice' makes you employable, I argue that it contributes to bridging the so-called theory-practice gap for students. After all, this assumption arguably encourages students to learn how to integrate what they are taught on campus and at placements under the labels of 'theory' and 'practice', respectively.

However, because this account uses the very distinction whereby theory and practice respectively mean the abstract research-based knowledge studied on campus, alongside the concrete activities carried out at work placements, it arguably also reinforces the message that 'theory' and 'practice' are essentially different. I argue that this means that the said account also contributes to creating the gap because this message arguably encourages students to look for and notice gaps between their on-campus and work placement-based training, and also to believe that these are theory-practice gaps per se.

A final quotation belonging to the theory and practice account is now outlined. This quotation is about how Herman Schneider concluded that students need training in both 'theory' and 'practice' and was stated in the ca. 1930 newspaper article called A university based on new idea. The quotation is written in connection with a key message of this 
article, i.e. that students must know how to integrate 'theory' into 'practice' to become useful in and thus ready for professional work:

During his years at college he had supported himself by working in an architect's office ... He knew from experience how much he had learned that could not be taught in the classrooms alone; he also knew what his first master lacked in the way of schooling that might have made him a far more able and useful citizen, a constructor and builder instead of a mere carpenter (Stearns ca. 1930 , p. 82).

By being written in this context, this quotation implies that if you have not acquired both 'practical experience' and formal schooling you will either lack the knowledge in 'theory' or the knowledge in 'practice' that you must both have and learn to integrate to become employable. The quotation also demonstrates that the theory and practice account and its two underlying assumptions are not just elements of the present WIL discourse. While the said account arguably not only contributes to creating the so-called theory-practice gap for students, it reinforces, in itself and together with the practice acclaiming account, the very dualistic meaning ascribed to graduate employability that arguably contributes to primarily creating this gap. Before I problematise this meaning further, discuss the potential value of a non-dualistic alternative to said meaning and how to possibly establish such an alternative, it is necessary to clarify a limitation within the documents studied. These documents tend to be written from the employer perspective that graduates must be able to deal with the conditions existing in working life, which can explain why the documents tend to imply that formal school activities such as book studies do not make you prepared for these conditions.

This scepticism of formal schooling remains alive at present (Letts 2019) but is also challenged (Masschelein and Simons 2013), and not all employers outside university are sceptical of formal schooling. By confirming that the two accounts of the dualistic meaning ascribed to graduate employability I examined are often emphasised in contemporary WIL research, I argue that, despite the above limitation of the documents, I have examined accounts that are widely established.

\section{Discussion}

I have problematised the dualistic meaning ascribed to graduate employability as research has generally ignored that this meaning arguably contributes primarily to creating the so-called theory-practice gap for students. Said meaning is linked specifically to the traditional work readiness interpretation of graduate employability, ensuring that this interpretation remains an established one.

While research has criticised this interpretation for ignoring that employability is not only about being ready for but also about being able to challenge and change the ways of working established in a profession (Crisp, Higgs and Letts 2019), it has generally not recognised this link. The link is that the work readiness interpretation belongs to the dualistic way of ascribing meaning to graduate employability and reflects the established dualistic notion that the working-life domain existing outside HEIs is the 'real world' that students must be prepared for. A non-dualistic way of ascribing meaning to graduate employability could, as research has called for, provide scope for alternatives to the work readiness interpretation (Trede and McEwen 2015). 
Such a method of ascribing meaning to graduate employability is now outlined, explaining how it could contribute decisively to avoiding the creation of the so-called theory-practice gap for students. One way of ascribing a non-dualistic meaning to graduate employability is to speak of an employable graduate as a graduate who knows how research-based and informal theories (ideas and principles, etc.) are embedded in professional work and how they can be used in various ways. Such a way of speaking could not only encourage students to graduate as experts in how research-based and informal theories are and could be used in this work. It could also encourage students to view theory as a form of knowledge that, in a research-based and informal form, shapes daily professional work, rather than a form of knowledge that is absent from this work until they have successfully integrated it. In the sense that the former view can give students the realisation that theory is a form of knowledge that shapes daily professional work, I argue that the said non-dualistic way of ascribing meaning to graduate employability could avoid creating the so-called theory-practice gap.

I further argue that the usual WIL design is not really suited to giving students this realisation, since it implies that only one form of theory exists, and that this is the researchbased theory students study and shall bring to 'practice'. Furthermore, this WIL design institutionalises the very terminology whose dualistic way of ascribing meaning to graduate employability arguably contributes to primarily creating the so-called theory-practice gap. In this manner, the usual WIL design arguably contributes to creating this gap, and while it also gives students opportunities to bridge the gap, it seems reasonable to at least question how effective this WIL design really is when it comes to bridging the gap for students.

There is a research trend to promote third spaces as learning environments that could avoid creating this gap (Forgasz et al 2018). Third spaces have been described as environments operating at a distance and 'freely' from the learning environments students encounter at HEIs and at workplaces outside HEIs, forming hybrids of these environments that are able to illustrate how research-based and informal theories shape daily professional work (Forgasz et al 2018). The concept of third places has also been introduced to emphasise that to become the 'free' environments they are intended to be, such hybrids need their own habitats where they can take hold and grow, in relation to but outside the learning environments students encounter at HEIs and workplaces (see Björck and Johansson 2019; Björck 2020, who discussed physical forms of such habitats, though these could also be virtual).

However, while the kind of hybrid environments stated above are debated in research, they have not become established institutional arrangements that could counter the dualistic way of thinking about what theory and practice mean and how they relate to each other, as is spread by the usual WIL design. Thus, there is arguably a lack of environments in students' education that, in contrast to this WIL design, could really show students how research-based and informal theories shape professional work and thereby avoid implying to students that theory is a form of knowledge with limited use. Further discussions on how such environments can look like are needed if they are to become established arrangements. They could be physical and/or virtual sites that introduce students to a profession's daily work practices, with a pedagogical focus on them trying out how various researchbased and informal theories are and could be used in such practices alongside faculty and professionals working outside HEIs. It is also vital to note that there is no guarantee that establishing such sites would in fact have the potential effect discussed in this study.

However, because the theory-practice terminology and its dualistic way of ascribing meaning to graduate employability are institutionalised in and spread to students through the usual WIL design, the following argument could be put forward. Physical and/or virtual 
sites designed to embody how research-based and informal theories shape daily professional work could institutionalise a non-dualistic way of ascribing meaning to graduate employability, which could encourage students to see theory as a useful form of knowledge. Finally, I would like to emphasise that to avoid reproducing the neoliberal thinking whereby employability is framed as something individuals are responsible for, a non-dualistic way of ascribing meaning to graduate employability must embrace a perspective emphasised in research. The perspective is that not only students but also HEIs and employers are responsible for graduate's employability (Crisp, Higgs and Letts 2019).

Acknowledgements This work was supported by University West-thank you. I would also like to thank the employees at University West, the University of Cincinnati and the University of Waterloo who helped me gain access to the empirical material. A final 'thank you' goes to Göran Lassbo, Kristina Johansson and Tomasz Szkudlarek for all their constructive criticism throughout the writing process.

Funding Open access funding provided by University West.

\section{Compliance with Ethical Standards}

Conflict of interest The author declares that there is no conflict of interest.

Open Access This article is licensed under a Creative Commons Attribution 4.0 International License, which permits use, sharing, adaptation, distribution and reproduction in any medium or format, as long as you give appropriate credit to the original author(s) and the source, provide a link to the Creative Commons licence, and indicate if changes were made. The images or other third party material in this article are included in the article's Creative Commons licence, unless indicated otherwise in a credit line to the material. If material is not included in the article's Creative Commons licence and your intended use is not permitted by statutory regulation or exceeds the permitted use, you will need to obtain permission directly from the copyright holder. To view a copy of this licence, visit http://creativecommons.org/licenses/by/4.0/.

\section{References}

Allan, H., \& Evans, K. (2019). Reintegrating theory and practice in nursing. In Dyson, S \& McAllister, M. (Eds) Routledge International Handbook of Nurse Education (pp. 130-147).

Björck, V. (2020). The idea of academia and the real world and its ironic role in the discourse on Workintegrated learning. Studies in Continuing Education, 42(1), 1-16.

Björck, V., \& Johansson, K. (2019). Problematising the theory-practice terminology: a discourse analysis of students' statements on Work-integrated learning. Journal of Further and Higher Education, 43(10), 1363-1375.

Boud, D. (2012). Problematising practice-based education. In J. Higgs, R. Barnett, S. Billett, M. Hutchings, \& F. Trede (Eds.), Practice-based education: Perspectives and strategies (pp. 55-69). Rotterdam: Sense Publishers.

Celebrating 100 years of Co-op: Growth, Experience and Connections. (2006). Promotional document from the University of Cincinnati.

Clarke, M. (2018). Rethinking graduate employability: the role of capital, individual attributes and context. Studies in Higher Education, 43(11), 1923-1937.

CO-OP (2014). Promotional document from University West.

COOP - The education that will earn you more than just money. (1990s). Promotional document from University West.

Cooperative Education - Putting higher education to work. (1990s). Promotional document from University West.

Crisp, G., Higgs, J., \& Letts, W. (2019). The employability agenda. In J. Higgs, W. Letts, \& G. Crisp (Eds.), Education for employability (Volume 2): Learning for future possibilities (pp. 4-12). Leiden Boston: BRILL.

Dahlstedt, M., \& Fejes, A. (2017). Shaping entrepreneurial citizens: A genealogy of entrepreneurship education in Sweden. Critical Studies in Education, 60(4), 462-476. 
Fejes, A. (2010). Discourses on employability: Constituting the responsible citizen. Studies in continuing education, 32(2), 89-102.

Forgasz, R., Heck, D., Williams, J., Ambrosetti, A., \& Willis, L. D. (2018). Theorising the third space of professional experience partnerships. In J. Kriewaldt, A. Ambrosetti, D. Rorrison, \& R. Capeness (Eds.), Educating future teachers: Innovative perspectives in professional experience (pp. 33-47). Singapore: Springer.

Foucault, M. (1971). Orders of discourse. Social Science Information, 10(2), 7-30.

Foucault, M. (1972). The archaeology of knowledge. London: Routledge.

Foucault, M. (1984). The foucault reader. Pantheon. New York: Pantheon Books.

Foucault, M. (1990). The history of sexuality: An introduction, volume I. Trans. Robert Hurley. New York: Vintage.

Foucault, M. (1991). The Foucault Effect: Studies in governmentality. University of Chicago Press.

Garsten, C., \& Jacobsson, K. (2004). Learning to be employable: An introduction. In C. G. \& K. J. (Eds.), Learning to be employable: New agendas on work, responsibility and learning in a globalized world (pp. 1-22). New York: Palgrave Macmillan.

Gazier, B. (1998) Employability: definitions and trends. In Gazier, B. (ed.) Employability: Concepts and Policies. European Employment Observatory, Berlin.

Hearing about Cooperative and Vocational Education before the US House of Representatives' Committee on Education. (1914). Statement of Mr Herman Schneider. Washington, DC: Washington Government Printing Office.

Jackson, D. (2017). Developing pre-professional identity in undergraduates through work-integrated learning. Higher Education, 74(5), 833-853.

Jackson, D., \& Collings, D. (2018). The influence of work-integrated learning and paid work during studies on graduate employment and underemployment. Higher Education, 76(3), 403-425.

Jolly, J. L. (2009). Historical perspectives: The national defense education act, current STEM initiative, and the gifted. Gifted Child Today, 32(2), 50-53.

Lakes, R. (2011). Work-Ready Testing: Education and Employability in Neoliberal Times. Journal for Critical Education Policy Studies, 9(1), 317-340.

Lau, P. L., Baranovich, D. L., \& Leong, K. E. (2018). Enhancing work readiness: A review of career development of adolescents in Malaysia. International Journal, 3(8), 13-20.

Letts, W. (2019). University employability agendas, targets and strategies. In J. Higgs, W. Letts, \& G. Crisp (Eds.), Education for employability (Volume 2): Learning for future possibilities (pp. 21-36). Leiden Boston: BRILL.

Masschelein, J., \& Simons, M. (2013). In defence of the school. A Public Issue. Leuven: Education, Culture and Society Publishers.

Orr, C. M. (2002). Challenging the 'academic/real world' divide. In N. A. Naples \& K. Bojar (Eds.), Teaching feminist activism: Strategies from the field (pp. 36-53). New York: Routledge.

Raelin, J. A. (2016). Work-based (not classroom) learning as the apt preparation for the practice of management. Management Teaching Review, 1(1), 43-51.

Sin, C., \& Neave, G. (2016). Employability deconstructed: perceptions of Bologna stakeholders. Studies in Higher Education, 41(8), 1447-1462.

Sovilla, E. S., \& Varty, J. W. (2011). Cooperative and work-integrated education in the US, past and present: Some lessons learnt. In R. K. \& K. E. Zegwaard (Eds.), International handbook for cooperative and work-integrated education: International perspectives of theory, research and practice (2nd ed., pp. 3-15). Lowell, MA: World Association for Cooperative Education.

Stearns, M. M. (Ca. 1930). A university based on a new idea. Publisher Unknown.

Suleman, F. (2018). The employability skills of higher education graduates: insights into conceptual frameworks and methodological options. Higher Education, 76(2), 263-278.

The University of Cincinnati's website. Accessed 5 November 2018. https://ceas.uc.edu/future_students/ Coop/professional_practicefacultystaffforengineering.html.

Tomlinson, M. (2017). Forms of graduate capital and their relationship to graduate employability. Education+ Training, 59(4), 338-352.

Trede, F., \& McEwen, C. (2015). Early workplace learning experiences: What are the pedagogical possibilities beyond retention and employability? Higher Education, 69(1), 19-32.

University of Waterloo Admissions Brochure for degree programmes in Accounting and Financial Management (2005).

University of Waterloo Undergraduate Admissions Handbook (1977).

University West's website. Accessed 30 September 2019. https://www.hv.se/utbildning/intervjuer/grundniva/ maskiningenjor. 
Webb, H. S. (2013). The splendid and the savage: The dance of the opposites in indigenous Andean thought. Journal of Transpersonal Research, 4(1), 69-93.

Zegwaard, K. E., \& Rowe, A. D. (2019). Research-informed curriculum and advancing innovative practices in work-integrated learning. International Journal of Work-Integrated Learning, 20(4), 323-334.

Publisher's Note Springer Nature remains neutral with regard to jurisdictional claims in published maps and institutional affiliations. 